\title{
SOME ASPECTS OF CARDIOVASCULAR MORTALITY IN SOUTH AFRICA
}

\author{
BY \\ A. M. ADELSTEIN \\ From the Department of Social and Preventive Medicine, University of Manchester
}

In many countries cardiovascular diseases, particularly coronary artery disease and hypertension, are the major cause of death and disability in adult life (Puffer and Verhoestrate, 1958). There are wide variations in the reported mortality rates from coronary artery disease both between countries and, within countries, between communities and between the sexes. The mortality from coronary artery disease among White males of the U.S.A. is an example of a high rate, and investigations have shown that in South Africa there are extreme differciaces in incidence and in mortality between the various social categories.

In this paper mortality trends from selected causes of cardiovascular disease in South African ethnic categories, in persons above 30 years of age, are compared with one another and also with corresponding mortality trends in the White population of the U.S.A. The death rates are depicted by graphs on logarithmic scales on which relative changes with age are well demonstrated.

South African official vital statistics are classified in categories which refer to the ethnic origins of the population, namely Africans, Whites, Coloureds, and Asians, their estimated numbers in 1958 being $9,160,000,3,007,200,1,362,800$, and 436,700 respectively. The Coloureds are descended from Whites, Africans (including Hottentots), and slaves of many races from Malaya, Ceylon, West Africa, Mozambique, and Madagascar. The Asians are almost entirely of Indian descent. The South African official policy has been to treat these categories as social groups and to attempt to maintain their discrete identities. There are marked differences between them in standards of living and in cultural patterns and a number of publications have described differences in their patterns of disease, attempting to relate such differences to genetic or environmental, and particularly to dietetic, factors (Bronte-Stewart, Keys, and Brock, 1955; Brock and Bronte-Stewart, 1955; Bersohn and Wayburne, 1956; Higginson and Pepler, 1954; Laurie and Woods, 1958; Keys, 1956; Walker and Arvidsson, 1954; Antonis and Bersohn, 1960; Gillman and Gillman, 1951).

\section{DATA}

Most of the South African mortality rates presented here were calculated from figures supplied by the Department of Census and Statistics and from the W.H.O. Epidemiological and Statistical Reviews for 1956 and 1957. The data of the South African White population for the period 1951-58 formed the basis of the analysis. After certain trends had become apparent, figures for the other ethnic categories were obtained, but these were not readily available for the same time-span as those for the White population. When comparing mortality of the White population with that of the Coloureds and Asians, the mean of the 5 years, 1954-58, was used for Whites and the mean of the 3 years, 1955-57, for the Coloureds and Asians. For the American population the years 1954 and 1956 were used. Averages of the South African annual rates were used to lessen the effect of sampling fluctuations arising from the relatively small numbers of deaths in a single year.

National mortality figures for Africans are not reliable because of incomplete and inaccurate death certification and population registration. In the City of Johannesburg the death certification of Africans is considered to be of a good standard, but the population registration is possibly seriously faulty, and thus the death registrations of the Africans of this city have been used to calculate proportional 
mortality rates only. The mean annual number of Africans in Johannesburg during the 3 years 1957-59, according to the official figures, was 474,510 .

In addition, data from a previous paper (Adelstein, 1961) of mortality rates from arteriosclerotic and degenerative heart disease among a group of South African White railway employees are presented, classified according to the degree of physical exertion required by their work. The data are drawn from records for the actuarial quinquennium 1954-59 of the pension fund to which the men belong as a condition of employment, and are discussed in relation to the possible effect of physical exertion on coronary artery disease. The men are employed in two categories; "officers" (clerks and administrators, including the higher-paid executives), and "employees" (men in a variety of occupations ranging from unskilled labourers to skilled artisans). In this industry there is hardly any voluntary interchange of categories; only a few men are promoted from employee to officer, and very little "drift" to the officer category is allowed as a consequence of illness. However, the little reclassification that does occur is from employee to officer. Causes of death were read from abridged death certificates and classified by the author in consultation with a colleague and without any reference to occupation. All the men belonged to a sick fund with comprehensive prepaid medical care so that the standard of certification should be high.

The groups of causes used throughout are those included in the Abbreviated List of fifty Causes of Tabulation of Mortality (W.H.O. 6th Revision, 1948), because these rates are published annually for many countries and are available in the Annual Statistical and Edpidemiological Review of W.H.O.

\begin{tabular}{|c|c|c|}
\hline Condition & $\begin{array}{c}\text { Detailed List } \\
\text { Numbers }\end{array}$ & Group \\
\hline $\begin{array}{l}\text { Vascular lesions affecting cen- } \\
\text { tral nervous system } \\
\text { Rheumatic fever } \\
\text { Chronic rheumatic heart dis- } \\
\text { ease .. } \\
\begin{array}{l}\text { Arteriosclerotic and degenera- } \\
\text { tive heart disease } . \\
\text { Other disease of heart } \\
\text { Hypertension with heart dis- } \\
\text { ease } \\
\text { Hypertension without mention } \\
\text { of heart }\end{array} . .\end{array}$ & $\begin{array}{l}330-334 \\
400-402 \\
410-416 \\
420-422 \\
430-434 \\
440-443 \\
444-447\end{array}$ & $\begin{array}{l}\text { B.26 } \\
\text { B.27 } \\
\text { B. } 28\end{array}$ \\
\hline
\end{tabular}

Group B.26 has been subdivided, the detailed rubric 420-Arteriosclerotic Heart Disease including Coronary Disease-being discussed separately.

\section{FINDINGS}

(1) Mortality of White, Coloured, and Asian South Africans in respect of All Cardiovascular Disease (Table I and Fig. 1).

The curves of the rates for the White population, based on large numbers, are regular, whereas those of the other groups show fairly marked sampling fluctuations.

\section{TABLE I}

DEATHS FROM ALL CARDIOVASCULAR DISEASE PER 100,000, BY AGE AND SEX IN SOUTH AFRICA (B.22, B.24-29) WHITES: MEAN 1954-58

COLOUREDS AND ASIANS: MEAN 1955-57

\begin{tabular}{|c|c|c|c|c|c|c|}
\hline \multirow{3}{*}{$\begin{array}{l}\text { Age } \\
\text { Group } \\
\text { (yrs) }\end{array}$} & \multicolumn{6}{|c|}{ Death Rate per 100,000} \\
\hline & \multicolumn{2}{|c|}{ Whites } & \multicolumn{2}{|c|}{ Coloureds } & \multicolumn{2}{|c|}{ Asians } \\
\hline & Males & Females & Males & Females & Males & Females \\
\hline $\begin{array}{l}30-34 \\
35-39 \\
40-44 \\
45-49 \\
50-54 \\
55-59 \\
60-64 \\
65-69 \\
70-74 \\
75-79\end{array}$ & $\begin{array}{r}42 \\
103 \\
195 \\
359 \\
627 \\
950 \\
1,463 \\
2,082 \\
2,823 \\
4,134\end{array}$ & $\begin{array}{r}21 \\
42 \\
88 \\
166 \\
274 \\
454 \\
774 \\
1,274 \\
2,084 \\
3,109\end{array}$ & $\begin{array}{r}81 \\
138 \\
215 \\
396 \\
699 \\
996 \\
1,864 \\
2,347 \\
2,976 \\
3,650\end{array}$ & $\begin{array}{r}60 \\
117 \\
265 \\
367 \\
577 \\
906 \\
1,767 \\
2,021 \\
2,712 \\
3,697\end{array}$ & $\begin{array}{r}35 \\
150 \\
322 \\
507 \\
940 \\
1,346 \\
2,024 \\
3,119 \\
4,025 \\
5,722\end{array}$ & $\begin{array}{r}49 \\
129 \\
161 \\
332 \\
836 \\
1,105 \\
2,087 \\
3,299 \\
4,822 \\
6,893\end{array}$ \\
\hline
\end{tabular}

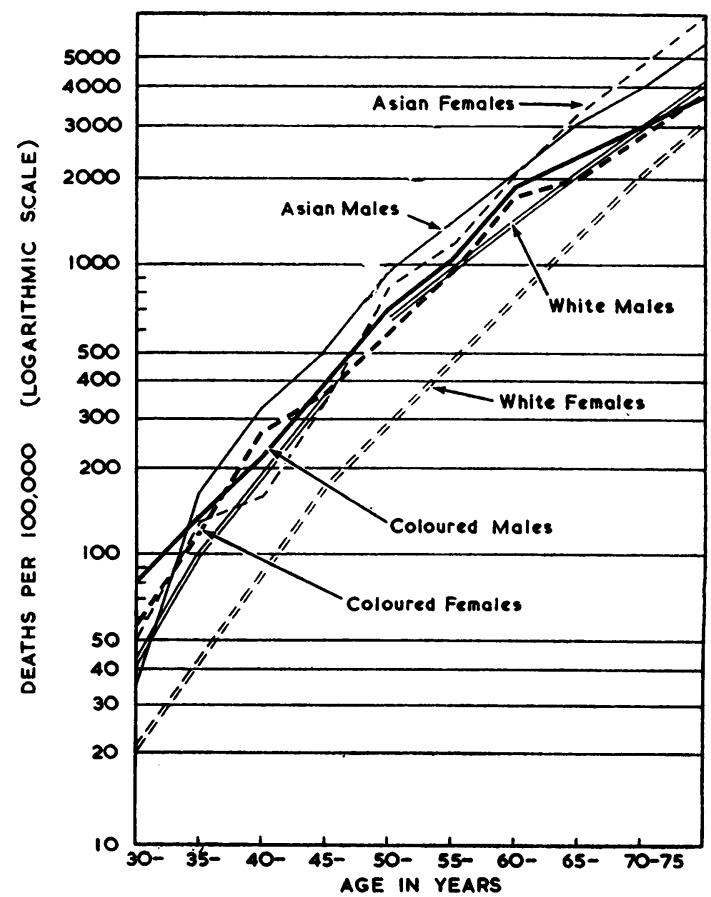

FIG. 1.-Deaths from all cardiovascular diseases (B.22, B.24-29) per 100,000 , by age and sex in South African White, Coloured, and Asian groups.

(Whites: Mean 1954-58). Coloureds and Asians: Mean 1955-57). 
(a) There is a marked sex difference in the mortality of the White population at all ages, the male:female ratio varying from $2 \cdot 44$ at age $35-40$, to $1 \cdot 33$ at age 75-80. Among the Asians and Coloureds, on the other hand, the male and female rates are similar.

(b) The mortality of White females is clearly below that of all the other groups at all ages.

(c) Among males, the Asians have the highest mortality at nearly every age above $35-40$ years, followed by Coloureds.

(2) Mortality of White, Coloured, and Asian South Africans in respect of Arteriosclerotic and Degenerative Heart Disease-B.26 (Table II and Fig. 2)

TABLE II

DEATHS FROM ARTERIOSCLEROTIC AND DEGENERATIVE HEART DISEASE (B.26) PER 100,000, BY AGE AND SEX IN SOUTH AFRICA WHITES: MEAN 1954-58 COLOUREDS AND ASIANS: MEAN 1955-57

\begin{tabular}{|c|c|c|c|c|c|c|}
\hline \multirow{3}{*}{$\begin{array}{l}\text { Age } \\
\text { Group } \\
\text { (yrs) }\end{array}$} & \multicolumn{6}{|c|}{ Death Rate per 100,000} \\
\hline & \multicolumn{2}{|c|}{ Whites } & \multicolumn{2}{|c|}{ Coloureds } & \multicolumn{2}{|c|}{ Asians } \\
\hline & Males & Females & Males & Females & Males & Females \\
\hline $\begin{array}{l}30-34 \\
35-39 \\
40-44 \\
45-49 \\
50-54 \\
55-59 \\
60-64 \\
65-69 \\
70-74 \\
75-79\end{array}$ & $\begin{array}{r}23 \\
76 \\
157 \\
295 \\
501 \\
732 \\
1,071 \\
1,509 \\
1,923 \\
2,669\end{array}$ & $\begin{array}{r}8 \\
17 \\
38 \\
82 \\
142 \\
249 \\
434 \\
678 \\
1,084 \\
1,491\end{array}$ & $\begin{array}{r}22 \\
57 \\
101 \\
231 \\
359 \\
473 \\
949 \\
1,015 \\
1,159 \\
1,592\end{array}$ & $\begin{array}{r}11 \\
43 \\
69 \\
122 \\
196 \\
321 \\
592 \\
650 \\
987 \\
945\end{array}$ & $\begin{array}{r}10 \\
85 \\
171 \\
303 \\
550 \\
647 \\
935 \\
1,368 \\
1,617 \\
2,810\end{array}$ & $\begin{array}{r}12 \\
41 \\
65 \\
140 \\
202 \\
499 \\
655 \\
1,165 \\
1,504 \\
2,430\end{array}$ \\
\hline
\end{tabular}

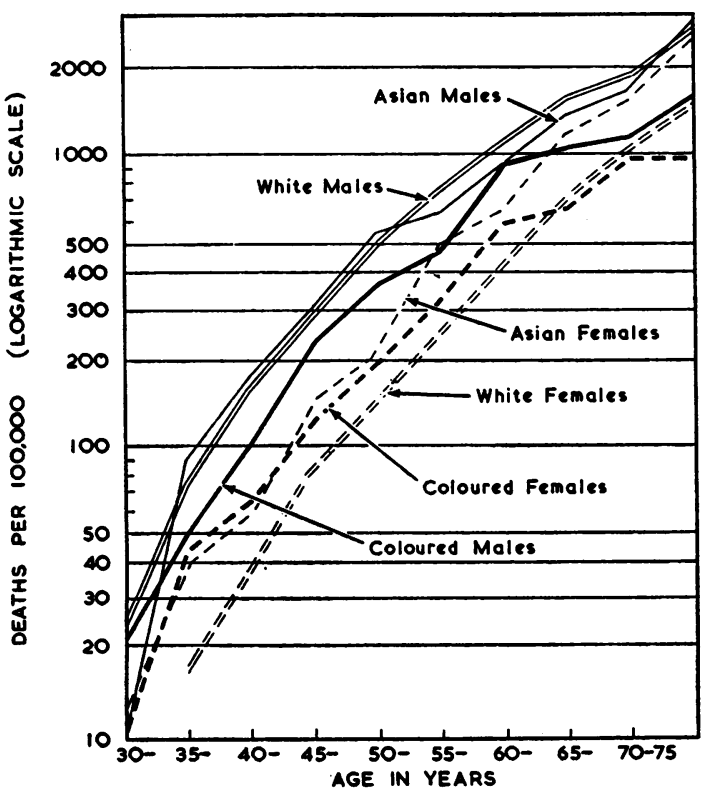

FIG. 2.-Deaths from arteriosclerotic and degenerative heart disease (B.26) per 100,000, by age and sex in South African White, Coloured (Whites: Mean 1954-58. Coloureds and Asians: Mean 1955-57). (a) Asian males have the highest rate up to age $\mathbf{5 0}$ after which the rate drops below that of White males.

(b) The death rate of Coloured males is below that of Asian and White males at every point, except at 30-35 years.

(c) The death rates of the three female categories are below those of their male counterparts at all ages, but the male:female ratio is highest in the Whites.

(d) Asian and Coloured females have higher mortality rates than White females at all ages.

(3) Mortality of White, Coloured, and Asian South Africans in respect of Arteriosclerotic Heart Disease, including Coronary Disease-420 (Table III and Fig. 3)

TABLE III

DEATHS FROM ARTERIOSCLEROTIC HEART DISEASE, INCLUDING CORONARY DISEASE (420) PER 100,000, BY AGE AND SEX IN SOUTH AFRICA

COLOUREDS AND ASIANS: MEAN, 1955-57

\begin{tabular}{|c|c|c|c|c|c|c|}
\hline \multirow{3}{*}{$\begin{array}{c}\text { Age } \\
\text { Group } \\
\text { (yrs) }\end{array}$} & \multicolumn{6}{|c|}{ Death Rate per 100,000} \\
\hline & \multicolumn{2}{|c|}{ Whites } & \multicolumn{2}{|c|}{ Coloureds } & \multicolumn{2}{|c|}{ Asians } \\
\hline & Males & Females & Males & Females & Males & Females \\
\hline $\begin{array}{l}30-34 \\
35-39 \\
40-44 \\
45-49 \\
50-54 \\
55-59 \\
60-64 \\
65-69 \\
70-74 \\
75-79\end{array}$ & $\begin{array}{r}22 \\
70 \\
142 \\
267 \\
450 \\
642 \\
917 \\
1,249 \\
1,552 \\
1,932\end{array}$ & $\begin{array}{r}6 \\
11 \\
25 \\
57 \\
101 \\
183 \\
330 \\
527 \\
778 \\
900\end{array}$ & $\begin{array}{r}24 \\
40 \\
79 \\
147 \\
216 \\
304 \\
603 \\
587 \\
605 \\
690\end{array}$ & $\begin{array}{r}10 \\
21 \\
37 \\
71 \\
113 \\
170 \\
313 \\
307 \\
333 \\
412\end{array}$ & $\begin{array}{r}18 \\
72 \\
158 \\
268 \\
398 \\
532 \\
832 \\
976 \\
1,089 \\
1,652\end{array}$ & $\begin{array}{r}5 \\
30 \\
42 \\
74 \\
176 \\
275 \\
548 \\
698 \\
958 \\
1,579\end{array}$ \\
\hline
\end{tabular}

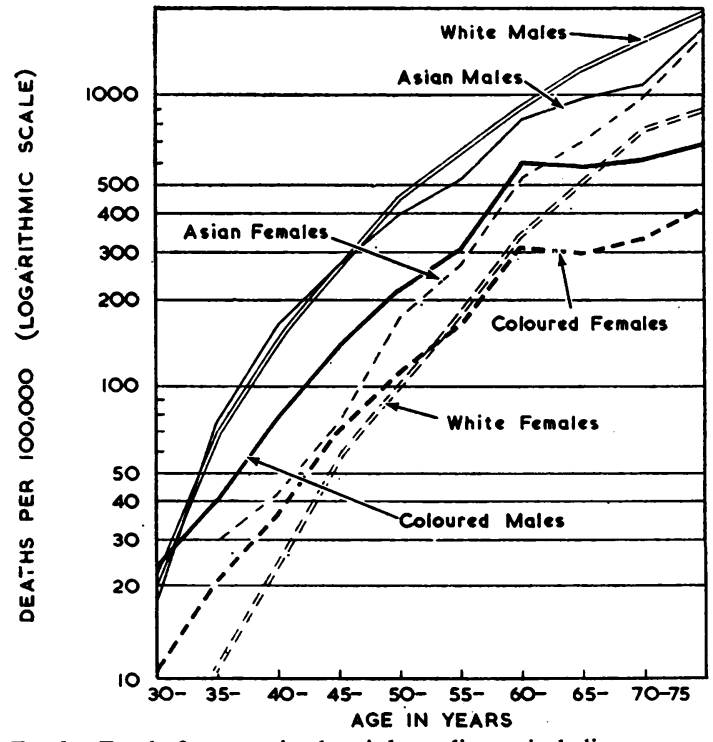

FIG. 3.-Deaths from arteriosclerotic heart disease, including coronary disease (420) per 100,000, by age and sex in South African White, Coloured, and Asian groups.

(Whites: Mean 1954-58. Coloureds and Asians: Mean 1955-57 
Group B.26 comprises three rubrics, 420,421 , and 422 , the two latter referring to "chronic endocarditis not specified as rheumatic" and "other myocardial degeneration". If Fig. 2 is compared with Fig. 3, it is clear that the mortality of White and Coloured males from 420 is similar to that from B.26, but in the other ethnic categories there are marked differences in trend, the rates from 420 falling well below those from B. 26 .

The mortality rates in Coloured females from 420 are very similar to those of White females, whereas from B.26 they are well above them.

(4) Mortality of White, Coloured, and Asian South Africans in respect of Hypertension (with Heart Disease, and without mention of Heart)-B.28, 29 (Table IV and Fig. 4)

TABLE IV

DEATHS FROM HYPERTENSION WITH HEART DISEASE AND WITHOUT MENTION OF HEART (B.28, B.29), PER 100,000 BY AGE AND SEX IN SOUTH AFRICA WHITES: MEAN 1954-58

COLOUREDS AND ASIANS: MEAN 1955-57

\begin{tabular}{|c|c|c|c|c|c|c|}
\hline \multirow{3}{*}{$\underset{\text { (yrs) }}{\text { Age }}$} & \multicolumn{6}{|c|}{ Death Rate per 100,000} \\
\hline & \multicolumn{2}{|c|}{ Whites } & \multicolumn{2}{|c|}{ Coloureds } & \multicolumn{2}{|c|}{ Asians } \\
\hline & Males & Females & Males & Females & Males & Females \\
\hline $\begin{array}{l}30-34 \\
35-39 \\
40-44 \\
45-49 \\
50-54 \\
55-59 \\
60-64 \\
65-69 \\
70-74 \\
75-79\end{array}$ & $\begin{array}{r}2 \\
5 \\
9 \\
12 \\
33 \\
48 \\
104 \\
141 \\
221 \\
314\end{array}$ & $\begin{array}{r}1 \\
5 \\
11 \\
15 \\
25 \\
48 \\
82 \\
139 \\
252 \\
393\end{array}$ & $\begin{array}{r}12 \\
14 \\
34 \\
67 \\
90 \\
171 \\
316 \\
483 \\
511 \\
532\end{array}$ & $\begin{array}{r}13 \\
23 \\
64 \\
78 \\
159 \\
200 \\
397 \\
527 \\
565 \\
833\end{array}$ & $\begin{array}{r}4 \\
17 \\
70 \\
55 \\
80 \\
203 \\
444 \\
670 \\
576 \\
1,217\end{array}$ & $\begin{array}{r}4 \\
18 \\
28 \\
81 \\
234 \\
217 \\
521 \\
998 \\
1,194 \\
1,818\end{array}$ \\
\hline
\end{tabular}

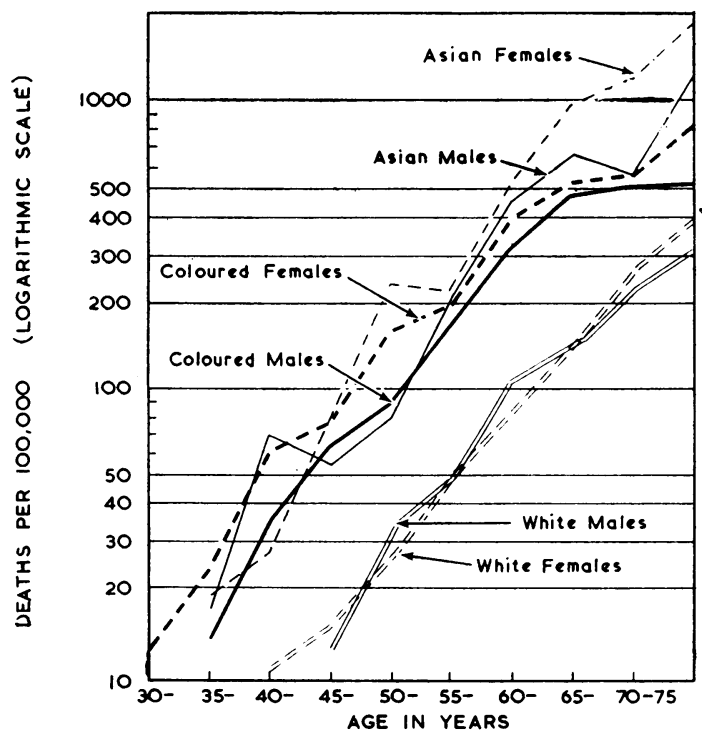

FIG. 4.-Deaths from hypertension with heart disease and without mention of heart (B.28, B.29) per 100,000 , by age and sex in South (Whites: Mean 1954-58, Coloured, and Asian groups.

(Whites: Mean 1954-58. Coloureds and Asians: Mean 1955-57).
Two clear trends are evident:

(a) Within each ethnic category, the sexes have similar mortality rates at all ages.

(b) The rates for Asians and Coloureds are considerably higher than that for Whites at all ages.

(5) Mortality of White, Coloured, and Asian South Africans in respect of Vascular Lesions affecting the Central Nervous System-B.22 (Table V and Fig. 5)

The trends are similar to those noted above in paragraph 4.

TABLE $V$

DEATHS FROM VASCULAR LESIONS AFFECTING THE CENTRAL NERVOUS SYSTEM (B.22) PER 100,000, BY AGE AND SEX IN SOUTH AFRICA WHITES: MEAN, 1954-58 COLOUREDS AND ASIANS: MEAN, 1955-57

\begin{tabular}{|c|c|c|c|c|c|c|}
\hline \multirow{3}{*}{$\begin{array}{l}\text { Age } \\
\text { Group } \\
\text { (yrs) }\end{array}$} & \multicolumn{6}{|c|}{ Death Rate per 100,000} \\
\hline & \multicolumn{2}{|c|}{ Whites } & \multicolumn{2}{|c|}{ Coloureds } & \multicolumn{2}{|c|}{ Asians } \\
\hline & Males & Females & Males & Females & Males & Females \\
\hline $\begin{array}{l}30-34 \\
35-39 \\
40-44 \\
45-49 \\
50-54 \\
55-59 \\
60-64 \\
65-69 \\
70-74 \\
75-79\end{array}$ & $\begin{array}{r}5 \\
11 \\
20 \\
44 \\
88 \\
161 \\
279 \\
415 \\
657 \\
1,127\end{array}$ & $\begin{array}{r}4 \\
13 \\
29 \\
65 \\
103 \\
155 \\
253 \\
429 \\
734 \\
1,204\end{array}$ & $\begin{array}{r}12 \\
32 \\
57 \\
79 \\
237 \\
342 \\
576 \\
829 \\
1,280 \\
1,526\end{array}$ & $\begin{array}{r}13 \\
17 \\
101 \\
148 \\
220 \\
364 \\
734 \\
828 \\
1,145 \\
1,907\end{array}$ & $\begin{array}{r}11 \\
43 \\
65 \\
142 \\
275 \\
496 \\
625 \\
1,059 \\
1,806 \\
1,641\end{array}$ & $\begin{array}{r}4 \\
51 \\
56 \\
96 \\
378 \\
388 \\
833 \\
1,136 \\
2,123 \\
2,645\end{array}$ \\
\hline
\end{tabular}

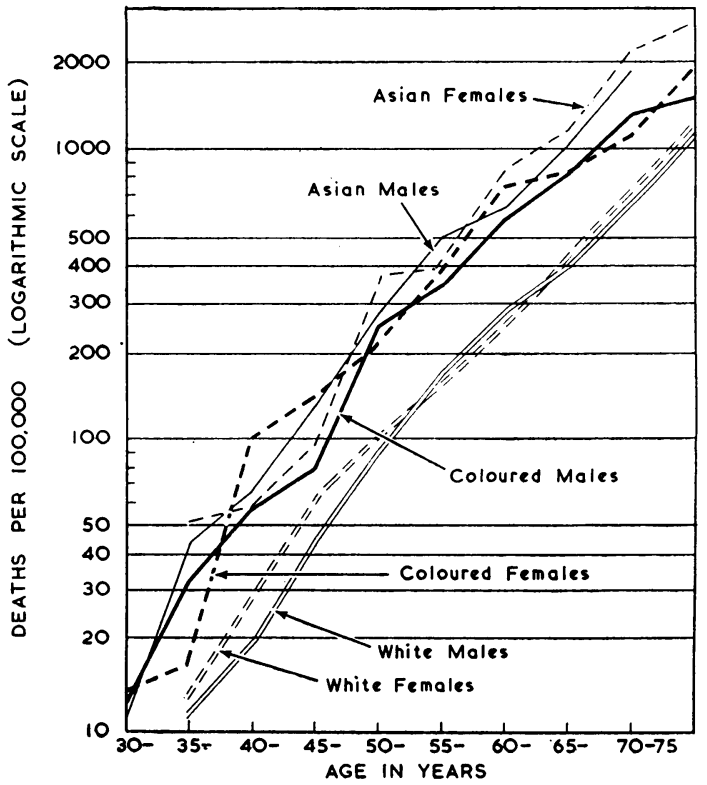

Fig. 5.-Deaths from vascular lesions affecting central nervous system (B.22) per 100,000, by age and sex in South African White, Coloured

(Whites: Mean 1954-58. Coloureds and Asians: Mean 1955-57). 
(6) Proportional Death Rates from all Cardiovascular Disease among Whites (Mean, 1954-58), Coloureds, and Asians of the South African population (Mean, 1955-57) and among Africans of the City of Johannesburg (Mean, 1957-59) (Fig. 6, overleaf).

MALES.-In White males deaths from arteriosclerotic heart disease including coronary disease (420) constitute a greater proportion of cardiovascular deaths than in Asians, Coloureds, and Africans. At each age group among Whites the proportion is more than 50 per cent. and at age $40-45$ years it is nearly 75 per cent.

In Asians also, this cause (420) accounts for a high proportion of deaths, though not as high as in the Whites; as seen in paragraph 3, however, Asian death rates from 420 approximate closely to those of the Whites. The proportion of deaths from 420 is less in Asians than in Whites mainly because of the higher mortality among Asians from vascular lesions of the central nervous system and from hypertension.

Among Coloured males, also, the proportion of deaths from vascular lesions and from hypertensive disease is high, and resembles that for Asians, while the proportion of deaths from arteriosclerotic heart disease (420) is lower (except in age group 30-35).

Among African males the pattern of the distribution of cardiovascular disease differs markedly from that of the other ethnic categories. The proportion for arteriosclerotic heart disease (420) is extremely low and that for vascular lesions of the central nervous system and hypertension is high, as in the Coloureds and Asians; among the Africans there are more deaths from hypertension than from vascular lesions, whereas the reverse is true for Coloureds and Asians. Among Africans the groups of other diseases (B.24, 25, 27) are large at each age.

Females.-In each ethnic category the proportion of deaths from arteriosclerotic heart disease is lower than in the corresponding male category. Particularly in the Africans is the rate from arteriosclerotic heart disease low, while that for hypertension and vascular disease of the central nervous system is high. Like African males and unlike the Coloureds and Asians, African females have more deaths from hypertension than from vascular lesions.

(7) Mortality of White Populations of South Africa and U.S.A. (B.26) from Arteriosclerotic and Degenerative Heart Disease (Fig. 7).

South African White males have higher rates for B.26 than the Americans up to the 50 to 55-year age group, and the females up to the 60 to 65 -year age group; above these ages the rates for South Africans in 1954-58 fall below those for Americans in 1956 (Fig. 7, overleaf, p. 35).

The difference in mortality rates between South Africans and Americans are more marked in the females than in males, although the pattern is similar being higher in South Africans up to the 60 to 65 -year age group and lower thereafter. The male : female ratios are higher in the American population than in the South Africans up to the age group 55 to 60 years.

Data for arteriosclerotic heart disease including coronary disease $(420)$ were not readily available for the U.S.A. for the same year as that given above, but the figures for the year 1954 are shown for 10-year age groups in Table VI. The trends are similar to those described for B.26. The mortality rate is higher in the South African males and females than in the corresponding Americans up to age 54, after which the American rate is higher.

TABLE VI

DEATHS FROM ARTERIOSCLEROTIC HEART DISEASE INCLUDING CORONARY DISEASE (420) PER 100,000, BY AGE AND SEX IN WHITES SOUTH AFRICA: MEAN, 1954-58 U.S.A.: 1954

\begin{tabular}{c|r|r|r|r}
\hline \multirow{2}{*}{$\begin{array}{c}\text { Age } \\
\text { Group }\end{array}$} & \multicolumn{2}{|c|}{ Males } & \multicolumn{2}{c}{ Females } \\
\cline { 2 - 3 } & \multicolumn{1}{|c|}{ S.A. } & U.S.A. & \multicolumn{1}{|c}{ S.A. } & \multicolumn{1}{|c}{ U.S.A. } \\
\hline & & & & \\
$35-44$ & 107 & 81 & 13 & 12 \\
$45-54$ & 339 & 331 & 77 & 63 \\
$55-64$ & 758 & 839 & 245 & 262 \\
$65-74$ & 1,281 & 1,729 & 604 & 878 \\
$75-84$ & 1,965 & 3,285 & 1,029 & 2,331 \\
\hline
\end{tabular}

(8) Trend of Annual Mortality from Arteriosclerotic and Degenerative Heart Disease among White South Africans (Fig. 8, overleaf, p. 36) and Coloured South Africans (Fig. 9, overleaf, p. 36).

The annual mortality is shown at selected age groups in Whites from 1949 to 1958 and in Coloureds from 1951 to 1958.

The lines show much random fluctuation. Among Whites the trend increases with time at all ages, the increase ranging from about 10 to 20 per cent. in the 10-year period.

In Coloured males a similar situation is observed but among Coloured females the increase appears only in the age groups above 60 years.

(9) Mortality from Arteriosclerotic and Degenerative Heart Disease (B.26) among White South African Railwaymen (Tables VII and VIII).

The death rates are compared in two groupsclerks and executive officers on the one hand, and 


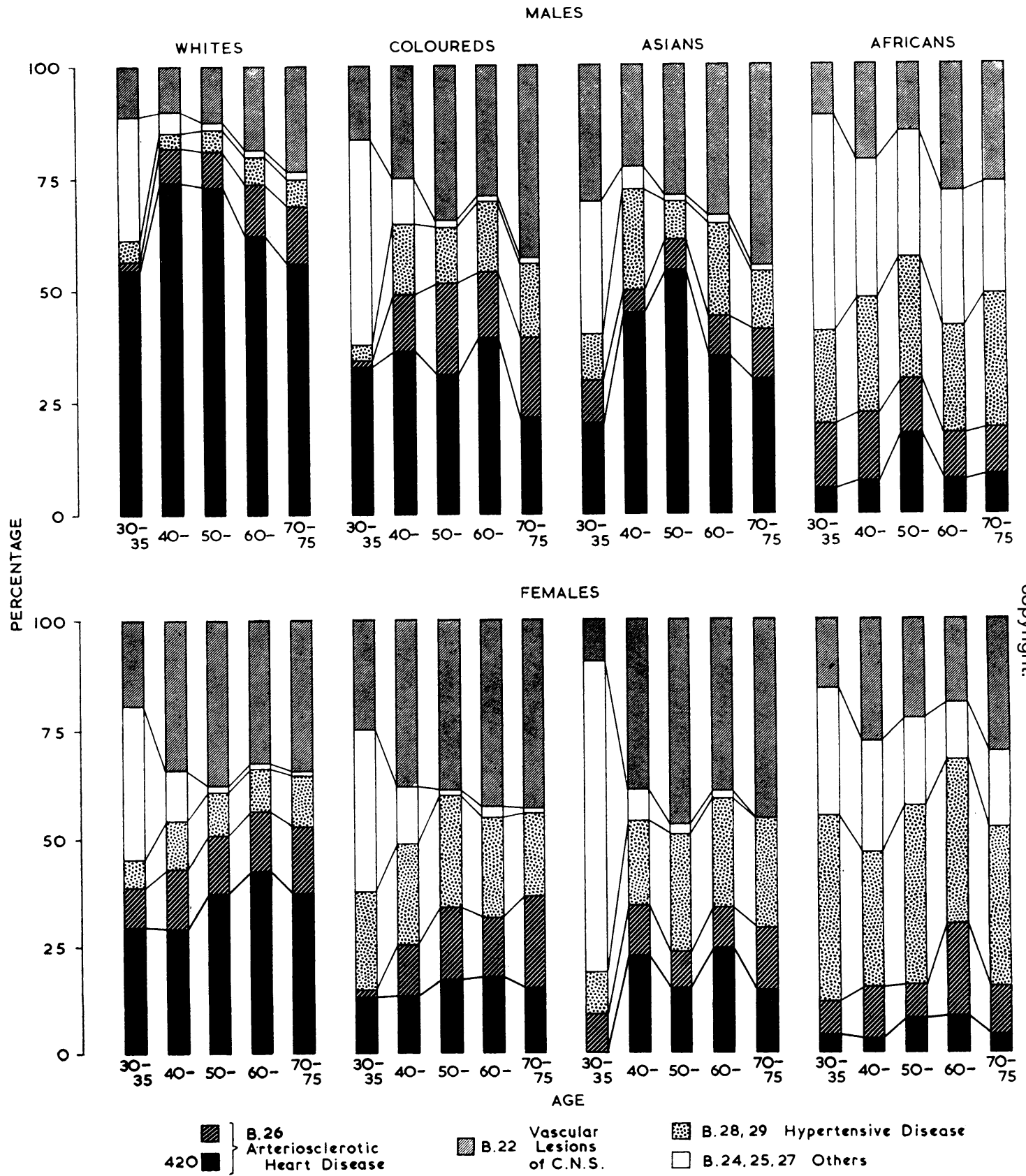
Fig. 6.-Percentage contribution of diagnostic sub-categories to all deaths from cardiovascular disease, by age and sex in South African

(Whites: Mean 1954-58. Coloureds and Asians: Mean 1955-57. Africans in Johannesburg: Mean 1957-59). 


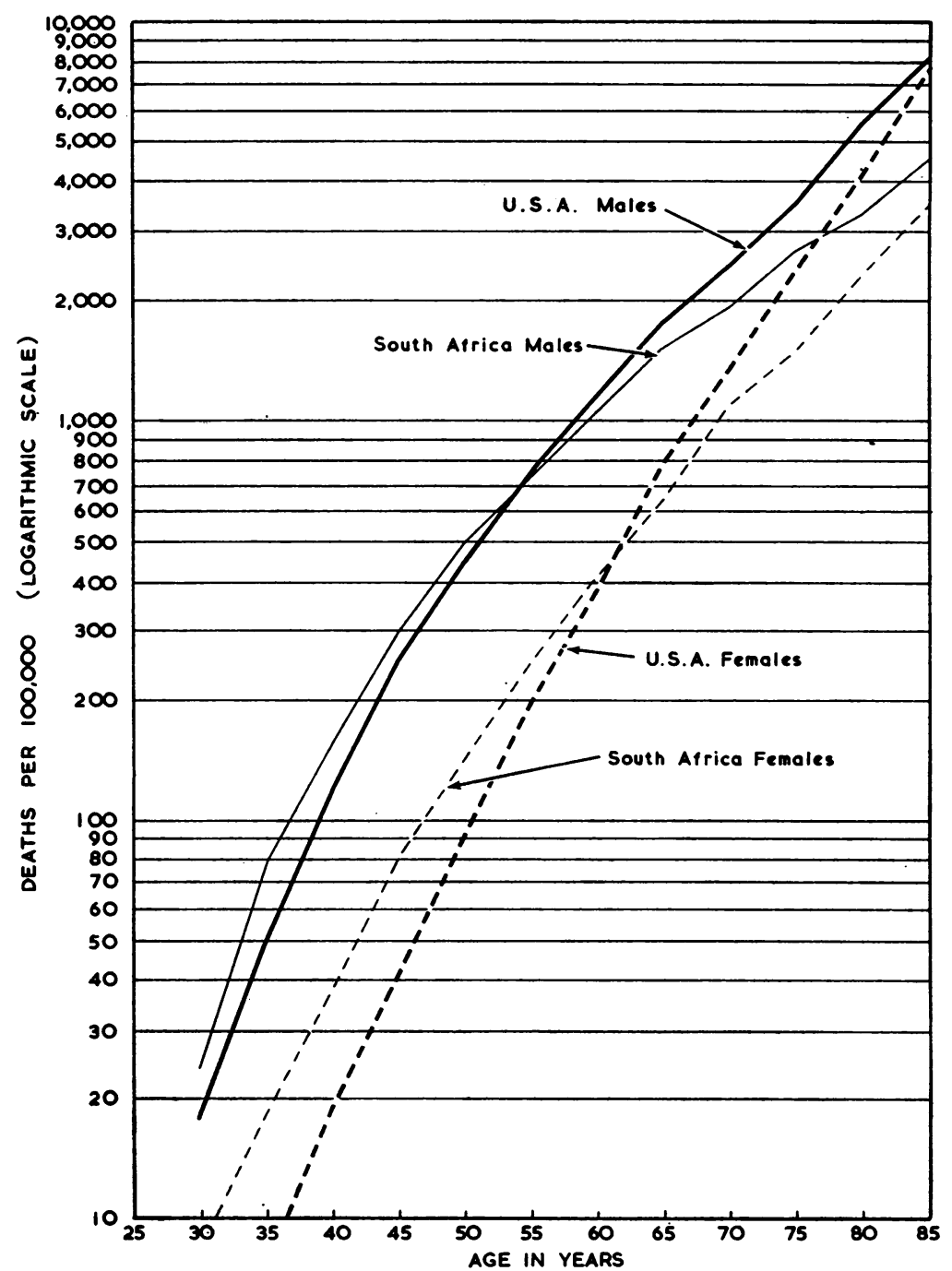

FIG. 7.-Deaths from arteriosclerotic and degenerative heart disease (B.26) per 100,000, by age and sex in Whites in South Africa and in the United States of America. (South Africa: Mean 1954-58. U.S.A.: 1956). 

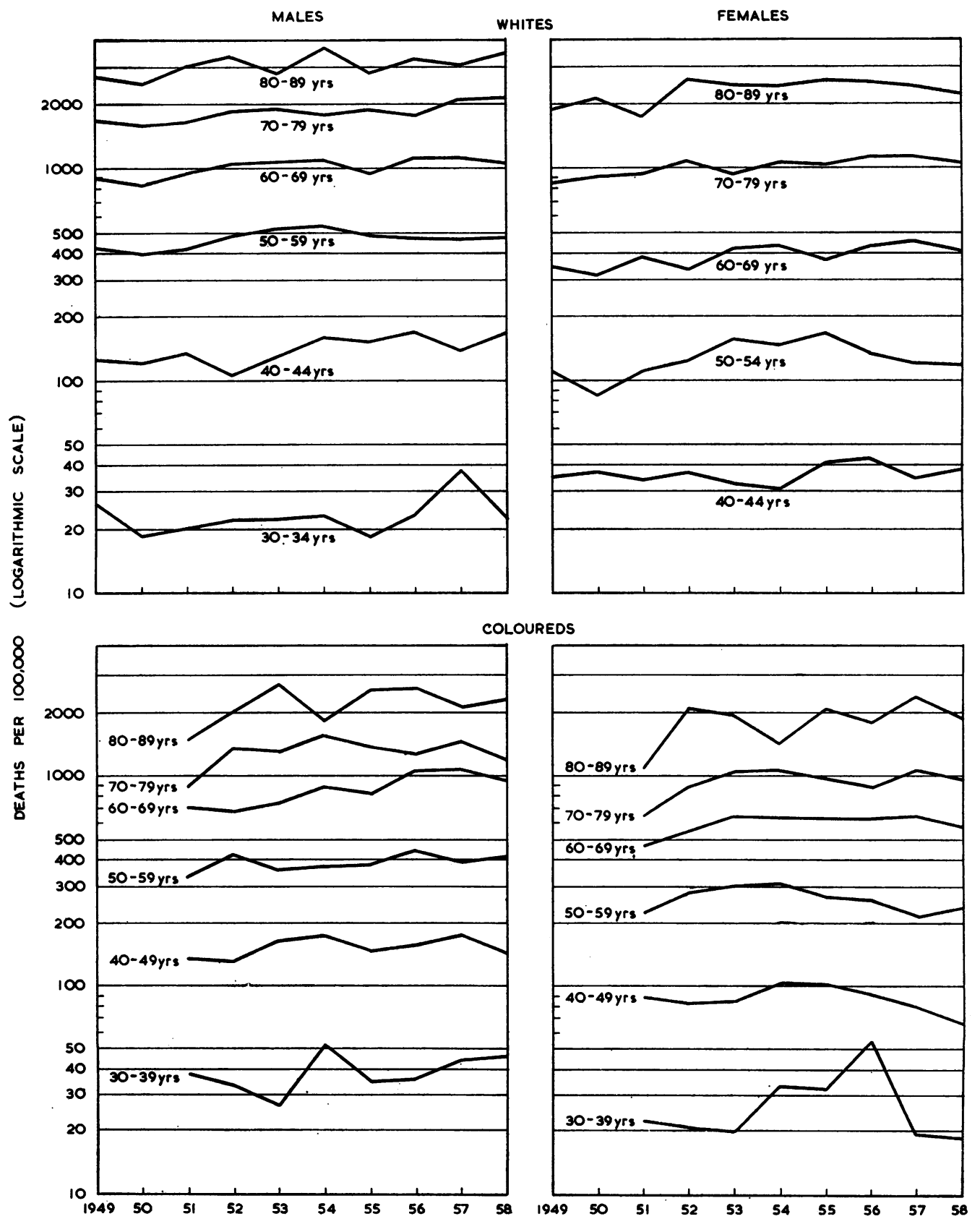

FIG. 8.-Deaths from arteriosclerotic and degenerative heart disease (B.26), by age and sex, in South African Whites, $1949-58$.

FIG. 9.-Deaths from arteriosclerotic and degenerative heart disease (B.26), by age and sex in South African Coloured persons, $1951-58$. 
men following occupations which require varying degrees of physical exertion on the other. The selective factors known to operate on this population are thought to enhance the death rate of the white-collar workers, if they had any effect at all. The deaths of both groups have been compared with an expected number in each 5-year age group based on the death rates of all South African men. These figures are shown in Table VII. No significant differences appear between the observed deaths and the expected deaths in either group.

\section{TABLE VII}

DEATHS FROM ARTERIOSCLEROTIC AND DEGENERATIVE HEART DISEASE (B.26) AMONG WHITE SOUTH AFRICAN RAILWAYMEN (1954-59)

(Expected numbers based on means of South African Male Death Rates for Years 1954-58)

\begin{tabular}{|c|c|c|c|c|}
\hline \multirow{3}{*}{$\underset{\text { (yrs) }}{\text { Age }}$} & \multicolumn{4}{|c|}{ No. of Deaths } \\
\hline & \multicolumn{2}{|c|}{$\begin{array}{c}\text { Officers } \\
\text { (Clerical and } \\
\text { Administrative) }\end{array}$} & \multicolumn{2}{|c|}{$\begin{array}{c}\text { Employees } \\
\text { (Almost entirely Physical) }\end{array}$} \\
\hline & Observed & Expected & Observed & Expected \\
\hline $\begin{array}{l}15-19 \\
20-24 \\
25-29 \\
30-34 \\
35-39 \\
40-44 \\
45-49 \\
50-54 \\
55-59\end{array}$ & $\begin{array}{r}-2 \\
5 \\
16 \\
18 \\
31 \\
40 \\
62\end{array}$ & $\begin{array}{r}\cdot 1 \\
\cdot 5 \\
1 \cdot 2 \\
3 \cdot 0 \\
11 \cdot 2 \\
19 \cdot 3 \\
34 \cdot 1 \\
55 \cdot 3 \\
62 \cdot 0\end{array}$ & $\begin{array}{r}2 \\
1 \\
8 \\
16 \\
28 \\
56 \\
126 \\
170 \\
113\end{array}$ & $\begin{array}{r}\cdot 2 \\
1 \cdot 5 \\
4 \cdot 5 \\
12 \cdot 2 \\
38 \cdot 1 \\
73 \cdot 6 \\
130 \cdot 0 \\
168 \cdot 3 \\
124 \cdot 5\end{array}$ \\
\hline $15-59$ & 174 & $186 \cdot 6$ & 520 & $552 \cdot 7$ \\
\hline 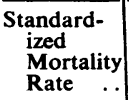 & \multicolumn{2}{|c|}{93 per cent. } & \multicolumn{2}{|c|}{94 per cent. } \\
\hline
\end{tabular}

The data of the railway population at risk are not available by age for any finer subdivision than "white collar" and "other" workers, but the records of deaths can be divided by occupational category, and the proportional mortality rates within each category calculated. In order to consider the possible effects of exertion at work on mortality due to arteriosclerotic and degenerative heart disease, each occupation was graded for physical exertion on a 5-point scale by four experienced industrial health inspectors and the mean rating was used. The number of deaths from arteriosclerotic and degenerative heart disease and from all causes (except accidents which are known to vary according to occupation) in each grade of exertion is shown separately for artisans and semi-skilled workers by age groups in Table VIII. The differences in the proportions of deaths due to arteriosclerotic and degenerative heart disease in each grade are not statistically significant and no trend is discernible.

\section{Discussion}

Despite the difficulties in drawing conclusions from mortality rates based on death certificates because of differing modes of certification and classification between communities, the clearly defined differences in the trends of mortality from cardiovascular diseases between ethnic categories (in one country), together with supporting evidence from clinical and pathological studies, suggest that these mortality rates are based on reasonably accurate diagnosis.

TABLE VIII

DEATHS FROM ARTERIOSCLEROTIC AND DEGENERATIVE HEART DISEASE (B.26), BY PHYSICAL DEMAND OF WORK IN WHITE SOUTH AFRICAN RAILWAYMEN (1954-59)

Grade 1: Least Strenuous, to Grade 5: Most Strenuous.

\begin{tabular}{|c|c|c|c|c|c|c|c|c|c|c|c|c|c|c|c|c|c|c|}
\hline \multirow{3}{*}{$\begin{array}{l}\text { Age } \\
\text { Group } \\
\text { (yrs) }\end{array}$} & \multirow{3}{*}{ Mortality } & \multicolumn{17}{|c|}{ No. of Deaths graded by Physical Demand of Work } \\
\hline & & \multicolumn{5}{|c|}{ Artisans } & \multicolumn{6}{|c|}{ Semi-Skilled } & \multicolumn{6}{|c|}{ Others } \\
\hline & & 1 & 2 & 4 & 5 & $1-5$ & 1 & 2 & 3 & 4 & 5 & $1-5$ & 1 & 2 & 3 & 4 & 5 & $1-5$ \\
\hline \multirow[t]{2}{*}{$50-59$} & \multirow[t]{2}{*}{$\begin{array}{l}\text { B. } 26 \\
\text { All deaths } \\
\text { (Per cent.)* }\end{array}$} & \multicolumn{2}{|r|}{$\begin{array}{l}5 \\
12 \\
41 \cdot 7\end{array}$} & $\begin{array}{l}11 \\
38 \\
28 \cdot 9\end{array}$ & $\begin{array}{l}14 \\
38 \\
36 \cdot 8\end{array}$ & $\begin{array}{l}30 \\
88 \\
34 \cdot 1\end{array}$ & $\overline{-}$ & $\begin{array}{c}2 \\
5 \\
40 \cdot 0\end{array}$ & $\begin{array}{c}9 \\
27 \\
33 \cdot 3\end{array}$ & $\begin{array}{l}26 \\
60 \\
43 \cdot 3\end{array}$ & $\begin{array}{c}6 \\
20 \\
30 \cdot 0\end{array}$ & $\begin{array}{c}43 \\
112 \\
38 \cdot 4\end{array}$ & $\begin{array}{l}19 \\
34 \\
55 \cdot 9\end{array}$ & $\begin{array}{c}81 \\
204 \\
39 \cdot 7\end{array}$ & $\begin{array}{l}48 \\
94 \\
51 \cdot 1\end{array}$ & $\begin{array}{l}10 \\
27 \\
37 \cdot 0\end{array}$ & $\begin{array}{l}10 \\
21 \\
47 \cdot 6\end{array}$ & $\begin{array}{l}168 \\
380 \\
44 \cdot 2\end{array}$ \\
\hline & & \multicolumn{2}{|r|}{$x^{2}=1 \cdot 63$} & $P$ & \multicolumn{2}{|c|}{$\cdot 5-\cdot 4$} & \multicolumn{3}{|c|}{$x^{2}=1 \cdot 51$} & $P$ & \multicolumn{2}{|c|}{$\cdot 7-\cdot 6$} & \multicolumn{3}{|c|}{$x^{2}=6 \cdot 00$} & $\boldsymbol{P}$ & \multicolumn{2}{|l|}{$\cdot 2-\cdot 1$} \\
\hline \multirow[t]{2}{*}{$40-49$} & \multirow[t]{2}{*}{$\begin{array}{l}\text { B.26 } \\
\text { All deaths } \\
\text { (Per cent.)* }\end{array}$} & \multicolumn{3}{|c|}{$\begin{array}{l}14 \\
37 \\
37 \cdot 8\end{array}$} & $\begin{array}{c}9 \\
19 \\
47 \cdot 4\end{array}$ & $\begin{array}{l}23 \\
56 \\
41 \cdot 1\end{array}$ & \multicolumn{3}{|c|}{$\begin{array}{l}5 \\
13 \\
38 \cdot 5\end{array}$} & \begin{tabular}{l|}
20 \\
43 \\
$46 \cdot 5$
\end{tabular} & $\begin{array}{c}7 \\
11 \\
63 \cdot 6 \\
\end{array}$ & \begin{tabular}{l|}
32 \\
67 \\
$47 \cdot 8$
\end{tabular} & $\begin{array}{l}12 \\
19 \\
63 \cdot 2\end{array}$ & \begin{tabular}{|c|}
51 \\
103 \\
$49 \cdot 5$ \\
\end{tabular} & \begin{tabular}{|l|}
29 \\
71 \\
$40 \cdot 8$ \\
\end{tabular} & \multicolumn{2}{|l|}{$\begin{array}{c}9 \\
28 \\
32 \cdot 1\end{array}$} & $\begin{array}{l}101 \\
221 \\
45 \cdot 7\end{array}$ \\
\hline & & \multicolumn{2}{|r|}{$x^{2}=\cdot 47$} & $P$ & \multicolumn{2}{|c|}{$\cdot 5-\cdot 4$} & \multicolumn{3}{|c|}{$x^{2}=1 \cdot 57$} & $P$ & \multicolumn{2}{|l|}{$.5-4$} & \multicolumn{3}{|c|}{$x^{2}=5 \cdot 71$} & $P$ & \multicolumn{2}{|l|}{$\cdot 2-\cdot 1$} \\
\hline \multirow[t]{2}{*}{$15-39$} & \multirow[t]{2}{*}{$\begin{array}{l}\text { B.26 } \\
\text { All deaths } \\
\text { (Per cent.)* }\end{array}$} & \multicolumn{3}{|c|}{$\stackrel{2}{33} 6 \cdot 1$} & $\begin{array}{c}3 \\
11 \\
27 \cdot 3\end{array}$ & $\begin{array}{c}5 \\
44 \\
11 \cdot 4\end{array}$ & \multicolumn{4}{|c|}{$\begin{array}{l}4 \\
12 \\
33 \cdot 3\end{array}$} & $\begin{array}{c}2 \\
5 \\
40 \cdot 0\end{array}$ & $\begin{array}{c}6 \\
17 \\
35 \cdot 3\end{array}$ & \multicolumn{2}{|l|}{$\begin{array}{l}23 \\
60 \\
38 \cdot 3\end{array}$} & \multicolumn{2}{|l|}{$\begin{array}{l}10 \\
41 \\
24 \cdot 4\end{array}$} & $\begin{array}{c}7 \\
37 \\
18 \cdot 9\end{array}$ & $\begin{array}{c}40 \\
138 \\
29 \cdot 0\end{array}$ \\
\hline & & \multicolumn{2}{|r|}{$x^{2}=1.88$} & $\boldsymbol{P}$ & \multicolumn{2}{|c|}{$\cdot 2-\cdot 1$} & \multicolumn{3}{|c|}{$x^{2}=\cdot 07$} & $P$ & $\cdot 8-7$ & & & $x^{2}=4$ & 79 & $P$ & $\cdot 0-0$ & 05 \\
\hline
\end{tabular}

* Deaths due to Arteriosclerotic Heart Disease as percentage of all Deaths (except Accidents). 
Although the pattern of mortality from cardiovascular diseases among White South Africans is in many respects similar to that of the White community of the U.S.A., in some important respects it is higher in South Africa. The largest portion of the cardiovascular deaths in adult life in these two White communities is from arteriosclerotic and degenerative heart disease (B.26) and the South African Whites have higher mortality rates from this cause than Americans up to about 60 years of age, the difference between the females of the two countries being more marked. The reverse relationship at higher ages is likely to be due to a larger degree of misclassification of deaths in South Africa where a higher proportion of deaths are placed in the category "senility, unknown, and ill-defined" (B.45).

The trends of mortality by age in the two White communities show a marked difference in magnitude between the sexes which lessens at the higher ages, and it is noticeable that the increases with age occur at very nearly constant rates. The curves depicting the mortality of women show no suggestion of any interruption in the steady increase of the mortality rate such as might be thought to occur at the climacteric.

Another important cause of cardiovascular disease in these two White communities is "vascular lesions affecting the central nervous system" (B.22). Here again the mortality trends are broadly similar, and here also the South African rates are somewhat higher up to about 65 years of age, after which the curves approximate.

A third cause of cardiovascular disease "hypertension with heart disease and without mention of heart" (B.28, 29), shows a close resemblance in the mortality curves for the two sexes in the two White communities, the South African rates being slightly lower at the highest ages. (The data for these latter two causes have not been presented.)

Among the South African ethnic categories the Asians, almost entirely of Indian descent, show the most unfavourable mortality rates from cardiovascular lesions. That from arteriosclerotic and degenerative heart disease is among the highest of the national rates on record, and that from vascular lesions of the central nervous system and hypertension is much higher at all adult ages than for the Whites. These high rates among Asians accord with the experience of hospital physicians such as Cosnett (1957) who showed that, among Indians in Natal, vascular disease, particularly cardiac and cerebral, is a common reason for admission to hospital.

Walker (1961a) has drawn attention to the high mortality from coronary heart disease among communities of Indian descent in Africa, stating that "the most dramatic increases in mortality are in Indian migrants to other Eastern or African Territories". Shaper and Jones (1959) state that "in the African population of Uganda coronary heart disease is almost non-existent. In the Asian community on the other hand coronary heart disease is a major problem".

Some of the differences in the recorded mortality rates in the U.S.A. between White and Negro communities are also seen in South Africa between the Whites on the one hand, and the Coloureds and Asians on the other. These differences include the following:

(i) The mortality from all cardiovascular causes is higher in the Coloureds (and Asians) than in the Whites in the corresponding age and sex groups;

(ii) The mortality for both sexes from all cardiovascular causes are very similar in the Coloureds (and Asians) whereas in the Whites there is a pronounced male predominance;

(iii) The mortality from hypertensive disease and vascular disease of the central nervous system (which is most probably largely due to hypertension) is much higher at all ages in both sexes among the Coloureds (and Asians) than among the Whites.

Although data for the African population of Johannesburg are not available for the calculation of age-specific death rates, it is clear from the proportional mortality figures that arteriosclerotic heart disease forms a relatively insignificant proportion of heart disease in Africans. It is likely that the deaths in Johannesburg Africans certified as being due to coronary heart disease are overstated, low as the total is. Higginson and Pepler (1954) have reported on a large number of necropsies carried out at the Baragwanath Hospital in Johannesburg (a large hospital (1,500 beds) for Africans). In 807 male and 521 female post mortem examinations of persons over 20 years of age there were four deaths in each sex from coronary heart disease, a mortality rate of about 0.6 per cent. They also reported seventy deaths in 532 necropsies of patients over 20 years of age from cerebral vascular disease. The high rate of arteriosclerosis of the cerebral arteries and of hypertension in Africans has been corroborated by other investigators (Becker, 1946; Ordman, 1946; Schwartz, Schamroth, and Seftel, 1958). Among the Africans the rubrics 433 and 434 (functional diseases of the heart, other and unspecified) form a large proportion of cardiovascular deaths, this being in accordance with reports that idiopathic heart disease not 
due to coronary heart disease is frequently encountered among Africans (Gillanders, 1951; Grusin, 1957; Higginson, Gillanders, and Murray, 1952; Seftel and Susser, 1961; Joint Seminar, Univ. Witwatersrand, 1957).

Category B.26, arteriosclerotic and degenerative heart disease, comprises rubrics 420,421 , and 422 , the latter two representing the "degenerative" cases. The relative size of 421 and 422 in the B.26 group varies markedly in different ethnic categories, and group B.26 or sub-group 420 should not therefore be used uncritically as a measure of arteriosclerotic (or coronary) heart disease. In South Africa the proportion of deaths classified in B.26 which belong to rubrics 421 and 422 is particularly large among the Africans, and is also much larger among the Coloureds and Asians than among the Whites.

In South Africa the trend of recorded mortality from arteriosclerotic and degenerative heart disease during the period 1949-58 has been rising in the Whites of both sexes and of all age groups and in the Coloured males. It is not possible to assess how much is due to an actual increase of the death rate and how much to changing fashions in the certification and classification of causes of death. Lew (1957), who analysed the trends of cardiovascular disease in the U.S.A. from 1940 to 1955 , stated that, in respect of coronary disease, "probable less than 15 per cent. of the increase in the death rate can be attributed to a real increase in the mortality from this disease". It is probable that some of the increase in the recorded mortality in South Africa is also due to changes in methods of classification and certification, but since there are such gross differences of mortality from this cause between communities, and since it appears that marked changes in the incidence of and deaths from this disease may occur after a community emigrates, it is not improbable that secular changes in mortality occur within stable communities when the environment changes and that the true death rate from coronary artery disease has been rising in South African Whites and Coloureds during the period under review.

The mortality records of the White South African railwaymen do not indicate that exertion at work played any significant role in respect of death from arteriosclerotic and degenerative heart disease. The number of deaths from this cause among the railwaymen is similar to that for all South African White males, and is among the highest of the national groups published, especially up to about 55 years of age. As pointed out in a report of the Metropolitan Life Assurance Company (1958), diverse and conflicting results have been reported in statistical studies of the relationship between socio-economic status and exercise on the one hand and arteriosclerotic heart disease on the other. Pell and D'Alonso (1961) have shown that, among employees of the Du Pont Organization, men in the highest and upper-middle salary brackets (who were executives, managers, and white-collar workers) had lower rates of attack of coronary thrombosis at all ages than the wage-roll employees (who were on the whole more physically active than the salaried men). However, investigations published in the United Kingdom, notably by Morris, Heady, Raffle, Roberts, and Parks (1953) and Morris (1959), indicate that among the populations studied by them exercise does have a protective effect against coronary thrombosis.

Since the mortality from arteriosclerotic heart disease is much higher among White communities in South Africa and in U.S.A. than it is in the United Kingdom, it is suggested that, in countries which have a very high mortality from arteriosclerotic heart disease, there may be particular causes which are not influenced by exercise or that these causes are potent enough in the particular circumstances to overcome any effect which exercise may have in other populations.

\section{SUMMARY}

The trends of mortality by age from cardiovascular diseases among adult South African Whites, Coloureds, Asians, and Africans are compared with one another and with trends in the U.S.A.

Mortality from all cardiovascular causes combined is much higher among White males than among females, whereas in Asians and Coloureds the mortality of the sexes approximate to each other at all ages, The Asian male and female mortalities from all cardiovascular causes are both higher than that of the White males at all corresponding ages, and ignoring random fluctuations, curves for the Coloured males and females lie between those for the Asian males and females on the one hand and for the White males on the other.

Mortality from arteriosclerotic and degenerative heart disease (B.26) is extremely high in Asian males and females at all ages, but it is also higher among the younger South African White males and females than among the corresponding Whites of the U.S.A.

Mortality from hypertensive disease and from vascular disease of the central nervous system is considerably higher among Coloureds and Asians than among Whites of both sexes and at all ages, and in this respect the situation is similar to the differences in the U.S.A. between Negroes and Whites. 
Judging from proportional rates and pathological studies, the Africans also have comparatively high mortality rates from hypertensive disease and from vascular disease of the central nervous system as well as from idiopathic heart disease, while their mortality from arteriosclerotic heart disease is extremely small.

Among White South African railwaymen no significant association was found between mortality from "arteriosclerotic and degenerative heart disease" and exertion at work. It is suggested that, in communities in which the incidence of arteriosclerotic heart disease is very high, the causal factors tend to swamp any protective influence which may be exerted by exercise in other and more favourable circumstances.

I am grateful to the Director of Census and Statistics and his staff for records of national mortality, and to the Medical Officer of Health of Johannesburg for the records of mortality among Africans. I am also grateful to Dr. A. R. P. Walker for his advice. Assistance in the computational work was made possible by a grant from the National Institutes of Health, U.S. Public Health Service.

\section{REFERENCES}

Adelstein, A. M. (1961). Med. Proc., 7, 286.

Antonis, A., and Bersohn, I. (1960). Lancet, 1, 998.

Association of Physicians of South Africa (1960). "Symposium: Cryptogenic Heart Disease in the Bantu of South Africa". S. Afr. med. J., 34, 913 .

Becker, B. J. P. (1946). S. Afr. J. med. Sci., 11, 97.

Bersohn, I., and Wayburne, S. (1956). Amer. J. clin. Nutr., 4, 117.

Brock, J. F., and Bronte-Stewart, B. (1955). Minnesota Med., 38, 852.

Bronte-Stewart, B. (1958). Brit. med. Bull., 14, 243.

$\longrightarrow$, Keys, A., and Brock, J. F. (1955). Lancet, 2, 1103.

Cosnett, J. E. (1957). S. Afr. med. J., 31, 1109.

Dawber, T. R., Moore, F. E., and Mann, G. V. (1957). Amer. J. Publ. Hlth., 47, Suppl. "Measuring the Risk of
Coronary Heart Disease in Adult Population Groups", p. 4.

Gillanders, A. D. (1951). Brit. Heart J., 13, 177.

Gillman, J., and Gillman, T. (1951). "Perspectives in Human Malnutrition", p. 224. Grune and Stratton, New York.

Grusin, H. (1957). Circulation, $16,27$.

Higginson, J., Gillanders, A. D., and Murray, J. F. (1952). Brit. Heart J., 14, 213.

and Pepler, W. J.'(1954). J. clin. Invest., 33, 1366.

Joint Seminar Univ. of the Witwatersrand: "Some African Cardiopathies", (1957). S. Afr. med. J., 31, 854.

Keys, A. (1956). J. chron. Dis., 4, 364.

Laurie, W., and Woods, J. D. (1958). Lancet, 1, 231.

Lew, E. A. (1957). J. chron. Dis., 6, 192.

Metropolitan Life Assurance Co. (1958). Stat. Bull., 39, No. 3, p. 6.

Morris, J. N. (1959). A.M.A. Arch. intern. Med., 104, 903.

Weady, J. A., Raffle, P. A. B., Roberts, C. G., and Parks, J. W. (1953). Lancet, 2, 1053.

Ordman, D. (1946). M. D. Thesis, Witwatersrand University, South Africa.

Pell, S., and D'Alonso, C. A. (1961). J. occup. Med., 3, 467.

Puffer, R. R., and Verhoestraete, L. J. (1958). Bull. Wld Hlth Org., 19, 315.

Schwartz, M. B., Schamroth, L., and Setfel, H. C. (1958). Med. Proc., 4, 275.

Seftel, H. C., and Susser, M. W. (1961). Brit. Heart J. 23, 43.

Shaper, A. G., and Jones, K. W. (1959). Lancet, 2, 534.

Smit, Z. M. (1957). S. Afr. J. Lab. clin. Med., 3, 29.

Walker, A. R. P. (1959). Amer. J. clin. Nutr., 7, 499. (1961a). Ibid., 9, 461.

(1961b). Nutr. Rev., 19, 257.

(1961c). Lancet, 1, 512.

- and Arvidsson, U. B. (1954). J. clin. Invest., 33, 1358.

and Grusin, H. (1959). Amer. J. clin. Nutr., 7, 264.

World Health Organisation (1948-49). "Manual of the International Statistical Classification of Diseases. Injuries, and Causes of Death". 6th Revision, adopted 1948. W.H.O. Geneva. (1960). "Annual Epidemiological and Vital Statistics, 1957”. W.H.O., Geneva. 